\title{
Contamination by Hazardous Elements in Low - Priced Children's Plastic Toys Bought on the local Markets of Karachi, Pakistan
}

\author{
Dur-e-Shahwar Gul \\ University of Karachi Faculty of Science \\ Anam Gul \\ University of Karachi \\ Asad Khan Tanoli ( $\square$ asad.tanoli@uok.edu.pk) \\ University of Karachi https://orcid.org/0000-0002-5876-0198 \\ Tehseen Ahmed \\ University of Karachi \\ Mubashir Ahmed \\ Global Environmental Lab Karachi
}

\section{Research Article}

Keywords: Toy contamination, Lead, Cadmium, Heavy Metals, Health Hazardous, Toy Analysis, low-priced Toys, Pakistan

Posted Date: November 10th, 2021

DOI: https://doi.org/10.21203/rs.3.rs-1001076/v1

License: (c) (i) This work is licensed under a Creative Commons Attribution 4.0 International License. Read Full License

Version of Record: A version of this preprint was published at Environmental Science and Pollution Research on March 7th, 2022. See the published version at https://doi.org/10.1007/s11356-022-19362-0. 


\section{Abstract}

Children's plastics toys maybe contain toxic metals to which infants and young children can be orally exposed and may pose acute or chronic adverse health effects. The objectives of this research were to evaluate the total metal concentrations (TMCs) of $\mathrm{Pb}, \mathrm{Cd}, \mathrm{Cr}, \mathrm{Ni}, \mathrm{Zn}, \mathrm{Cu}, \mathrm{and} \mathrm{Mn}$ in children's plastic Toys Bought in the local markets of Karachi, Pakistan, and compared TMCs to different regulatory limits. Total 44 children's plastic toys sourced in the Karachi local markets had analyzed by an atomic absorption spectrophotometer for heavy metals contaminations. These toy samples had divided into two groups; Plastic toys (DCT) and Plastic toys with paints or coatings (DPCT). For plastic toys, $83 \%$ (19) of samples had TMCs that exceeded European Union (EU) toy safety regulation limits for $\mathrm{Pb}$, and $65 \%$ (15) of samples that exceeded for $\mathrm{Cd}$. For plastic toys with paints or coating, $43 \%$ (9) of samples had TMCs that exceeded EU migration limits for $\mathrm{Pb}$ and $24 \%$ (5) for Cd. More than 20 samples exceeded the United States Consumer Product Safety Commission (U.S. CPSC), Canadian, and Bureau of Indian Standards (BIS) toy safety regulation limits. In toys samples $(\mathrm{n}=44)$ very high TMCs of $\mathrm{Pb}(64 \%), \mathrm{Cd}(45 \%), \mathrm{Cr}(5 \%)$, and $\mathrm{Ni}(2 \%)$ were observed. $\mathrm{Zn}, \mathrm{Cu}$, and $\mathrm{Mn}$ TMCs were also existing but below the Regulation limits. The Contamination levels of $\mathrm{Pb}, \mathrm{Cd}, \mathrm{Cr}$, and $\mathrm{Ni}$ and smaller extent of $\mathrm{Zn}, \mathrm{Cu}$, and $\mathrm{Mn}$ still pose health issues in children and may cause serious problems in their health.

\section{Introduction}

The research development of heavy metals is not a new area of science, having existed for more than a century. The study of heavy metals is called heavy metal science. It is a provocative field of science (kumar Das, singh Grewal et al. 2011). Many definitions of heavy metals have been in the literature based on atomic weight, density, physical characteristics, and chemical toxicity. Heavy metals are naturally occurring elements with a high atomic weight and five times the density of water. Heavy metals are a member of a loosely-defined subset of elements that exhibit metallic properties that includes transition metals, some metalloids, lanthanides, and actinides. it cannot be metabolized by the body, creates metal body burden, and cause metal accumulation (Yang and Massey 2019).

Human exposure to heavy metals is an important current problem. Consumer products may contain toxic chemicals which can affect consumer health and cause serious health problems, especially in young children because children are highly sensitive to exposure due to their physiological and developmental properties. Children have exposed to a certain level of metals via multiple pathways like food, air, soil, and water (Guney and Zagury 2013). Childhood exposure to environmental metals continues to be a major health concern. Hazardous elemental contamination in children's toys is a widespread problem. Children's toys may contain high levels of toxic metals. These toxic chemicals are already present in contaminated recycled material, or plastics materials which used to manufacture mostly low priced consumer goods and products, and some metals are added during the manufacturing process to provide or improve the brightness, softness, stability, and flexibility of the final product to make it more attractive for the young children (Negev, Berman et al. 2018). Use of metals as stabilizers in plastics during manufacturing, application of paint containing metal pigment in toys, and use of contaminated recycled plastic and electronic waste, or metals in toy production are the main reasons for hazardous metals contamination in children's toys (Guney and Zagury 2012). Numerous studies on toys contamination by harmful elements were report in different countries; (Greenway and Gerstenberger 2010) examined Pb in the plastic of children's toys collected from daycare centers in Las Vegas valley, Nevada. (Sindiku and Osibanjo 2011) reported the level of Pb, Cd, $\mathrm{Cr}$, and $\mathrm{Ni}$ in the plastic components of 51 children toy's imported to Nigeria. (Ahmad, Nasibullah et al. 2012) analyzed Pb, Cd, Ni, Zn, Cr, Co, and $\mathrm{Mn}$ in Leachates of 26 brands of plastic toys Purchased from Different Districts of UP, India. (Guney and Zagury 2013) examined As, Ba, $\mathrm{Cd}, \mathrm{Cr}, \mathrm{Cu}, \mathrm{Mn}, \mathrm{Ni}, \mathrm{Pb}, \mathrm{Sb}$, and Se in 72 toys and jewelry items purchased from the North American Market. (Kang and Zhu 2014) reported Pb, $\mathrm{Cr}, \mathrm{As}, \mathrm{Cu}, \mathrm{Ni}, \mathrm{Ba}, \mathrm{Cd}$, and $\mathrm{Sb}$ in 35 plastic toys bought on the Beijing market. (Cui, Li et al. 2015) tested for As, $\mathrm{Cd}, \mathrm{Sb}, \mathrm{Cr}, \mathrm{Ni}$, and $\mathrm{Pb}$ in 45 children's toys and jewelry purchased from Nanjing, China. (Sobhanardakani and Babaei 2016) examined As, Pb, Cd, and Cr in 30 children's plastic toys collected from Hamadan City. (Le ha 2017) reported $\mathrm{Zn}, \mathrm{Cr}, \mathrm{Cu}, \mathrm{Ni}, \mathrm{Mn}, \mathrm{Pb}, \mathrm{As}$, and $\mathrm{Cd}$ in 31 plastic toys in Hanoi, Vietnam. (Turner 2018) analyzed $\mathrm{As}, \mathrm{Ba}, \mathrm{Cd}, \mathrm{Cr}, \mathrm{Hg}, \mathrm{Pb}, \mathrm{Sb}$, and Se in 200 second-hand plastic toys sourced in the UK. (Issa and Alshatteri 2019) examined 14 toxic metals in 6 second-hand plastic infant items collected from markets of Kalar city, Iraq. (Mohammed, Dial et al. 2020) assessed Pb, Mn, $\mathrm{Ni}, \mathrm{Cr}, \mathrm{Cd}$, and $\mathrm{Cu}$ in 11 toys and 07 baby items sold in Trinidad and Tobago.

Heavy metals are employed as additions in polymers, such as paint pigments, plasticizers, UV stabilizers, fillers, colorants, antioxidants, processing aids, and flame retardants (Godoi, Santos Jr et al. 2009, Ozbek, Ustabasi et al. 2015, Ratnakumar, De Alwis et al. 2017). Polyvinyl chloride (PVC) is the most widely used polymer; it is also used to make soft and hard toys and contains heavy metals. PVC is used in toys to stabilize polymers and prevent deterioration from sunlight, heat, and wear that causes heavy metals liberation from children's toys. Vinyl contains chlorine, which requires the inclusion of metal stabilizers. Without a stabilizer, chlorine can damage the product by producing hydrochloric acid. The Consumer Product Safety Commission (CPSC) has proven via experiments that light and heat can cause vinyl toys to degrade and produce $\mathrm{Pb}$ dust. However, vinyl toys discharged $\mathrm{Pb}$ during regular product usage (Sindiku and Osibanjo 2011). Heavy metals can be transmitted from toys when young children constantly chew, lick, and suck on their toys and consume a certain quantity of these poisonous and dangerous chemicals through their typical hand-to-mouth action. Heavy metals are weakly bonded to the surface of the painted toys, allowing them to be released and causing a hazardous impact in the long run (Guney and Zagury 2014, Cui, Li et al. 2015, Le ha 2017). 
Heavy metals exposure can provide a long-term concern due to their ability to bio-accumulate. Toxic heavy metals can impair our brain functions, energy, neurological system, kidney, lungs, and other organ functioning. $\mathrm{Pb}$ is a neurotoxin that can cause lead poisoning, damage to the brain and nervous system, slowed growth and development, hearing and speech problems, learning disabilities, low IQ, Anemia, and kidney failure (Greenway and Gerstenberger 2010, O'Connor, Hou et al. 2018, Njati and Maguta 2019). On the other hand, cadmium (Cd) is a nephrotoxic, carcinogenic, and build of $\mathrm{Cd}$ in the kidney that causes kidney disease. Cd can cause a wide variety of acute and chronic effects in the neurological system and respiratory system, bone defects, kidney cancer, prostate cancer, and lung cancer (Turner 2019). Chromium (Cr) metal and $\mathrm{Cr}(\mathrm{III})$ compounds are not generally considered harmful to one's health. The most prevalent forms of chromium in the environment are $\mathrm{Cr}(\mathrm{III})$ and $\mathrm{Cr}(\mathrm{VI})$. However, hexavalent chromium is very hazardous and mutagenic when inhaled. $\mathrm{Cr}(\mathrm{VI})$ is a very active carcinogen at the cellular level. Human oral exposure to $\mathrm{Cr}(\mathrm{VI})$ has causes hepatotoxicity, which may lead to primary liver cancer and increase the likelihood of cancer patients' deterioration. (Guney and Zagury 2014, Karaś and Frankowski 2018).

Zinc(Zn), Nickel(Ni), Copper(Cu), and Manganese(Mn) are essential for life and are important requirements for good health, but excess and long-term exposure can be harmful and cause health difficulties. Excessive Unnecessary Zn absorption reduces Cu and iron (Fe) absorption. The free $\mathrm{Zn}$ ion is a powerful Lewis acid that can be caustic. Stomach acid contains hydrochloric acid, which quickly dissolves metallic $\mathrm{Zn}$ to form caustic zinc chloride. Because of the high solubility of the $\mathrm{Zn}$ ion in the acidic stomach, this chloride can damage the stomach lining, and excessive Zn can also damage nerve receptors in the nose, causing headaches and Anosmia means partial or total loss of one's sense of smell. (Ahmad, Nasibullah et al. 2012). Long-term exposure to Ni can cause skin irritation, decreased bodyweight, heart, and liver damage (Sindiku and Osibanjo 2011, Charehsaz, GÜVEN et al. 2014). Long-term exposure to Cu can cause Wilson's disease, a rare genetic disorder that causes Cu poisoning in the body, Anemia, stomach and intestinal irritation, and liver and kidney damage (Brewer 2010). A high level of Mn causes manganism, a biphasic disorder. An inebriated individual may exhibit obsessive behaviors, sadness, psychosis, and mood swings in the early stages. Late-stage manganism, which is comparable to Parkinson's disease, develops from early neurological signs. Monotone and delayed speech, weakness, forward-leaning stride, expressionless face, inability to move backward without falling, tremor, stiffness, and general difficulties with locomotion, dexterity, and balance are all symptoms (Ahmad, Nasibullah et al. 2012).

In the past, children's exposure to hazardous elements via ingestion of many consumer products has resulted in many cases with serious acute or chronic adverse effects, including death. (Njati and Maguta 2019) reviewed some cases related to contaminated metal Pb injuries in toys from the U.S., and other countries; A girl diagnosed with seizure disorder had a toy horse which was a recall due to a high level of $\mathrm{Pb}$ contamination which may cause seizures. Another little girl was diagnosed to have a high Pb level in her blood, playing with toys that were recalled. Another case where a small boy's hand started itching after playing with a remote-controlled toy car that contained Pb. Another one where a little boy opened a set of toy cars after 5 minutes, developed a huge red rash over his hands, and was diagnosed with $\mathrm{Pb}$ poisoning. the little boy experienced breathing problems and nausea and died the following day (Njati and Maguta 2019).

Millions of toys have been recalled in recent years due to chemical safety hazards such as; In June $20071.5 \mathrm{million}$ units were recalled that violated U.S. Government standard for Pb in paints. In January 2010 CPSC recalled 55,000 units that contained high levels of Cd. In June 2010, 12million promotional drinking glasses sold at Mc Donald's were recalled due to painted coating contained a high level of Cd (Becker, Edwards et al. 2010). The CPSC website for recall shows that more than 18million items have been withdrawn from the market due to high Pb levels between 2007-2018 and recall data from Canada's official website included a wider list bet 2007 -2018 1.6million products have been officially recalled for Pb contamination in 138incidents (Becker, Edwards et al. 2010, Guney and Zagury 2012, Njati and Maguta 2019, Guney, Kismelyeva et al. 2020)

In Pakistan, to the author's knowledge, this is the first scientific investigation that evaluates the presence of toxic contaminations in low-priced children's plastic toys randomly collected from the local markets in Karachi. For this purpose, in the first stage, only low-priced items are selected for analysis. Present research only focuses on total metals concentration (TMCs). If TMCs will exceed high numbers, then further bioaccessibility testing is required.

Due to the absence of National based toy safety regulation limits in Pakistan, or there are no Pakistan standards and quality control authority guidelines, especially for toys to ensure children's safety. Obtained results have compared from other regulations available in different countries and regions are mentioned in Table 1. Its includes, European Union (EU) Toy Safety Directive (European Council 2009), United States Consumer Product Safety Commission (U.S.CPSC) toy safety F963-11, Canadian limits (Government of Canada,2016-2018), and Bureau of Indian Standards (BIS) IS:9873 regulation limits.

The objectives of this research are as follows:

- To evaluate the current level of contamination in low-priced children's toys $(n=44)$ available in Karachi local markets in terms of total metals concentrations (TMCs) (Pb, Cd, Cr, Cu, Mn, Ni, and Zn).

- To compare the TMCs results with EU, U.S., Canada, and BIS Toy safety Regulations limits. 


\section{Materials And Methods Study Design}

Forty-four samples, including twenty-three plastic toys and twenty-one plastic toys containing paint or coating samples, were selected and purchased from different local markets in Karachi, Pakistan. Samples were randomly picked from local markets, stalls, mall stores, bargain stores, roadside vendors, and retail toy shops. Selecting those plastic toys which were low priced, design for small children around 3-5 years old, and mostly demanded too low-income groups. Collected samples include; cars, soft baby' toys, animals toys, balls, fruits toys, soft dolls, fishies, ships, planes type characters. All samples included in this research had grouped into two categories: children's plastic toys (DCT) and children's plastic toys with paint or coating (DPCT). All samples were coded and stored in their original packaging.

We tested for the following health-hazardous elements in terms of total metal concentration (TMCs); Lead (Pb), Cadmium (Cd), Nickel (Ni), Zinc (Zn), Chromium (Cr), Copper (Cu), and Manganese (Mn).

\section{Sample Preparation and Analysis}

Toys samples were weighted, and by using a cutter and scissors each toy body was sliced into extremely little pieces. Some samples were crushed and ground into powder. To create one composite sample for each toy, different parts of the sample were combined with different colors of the same toy and were kept in glass vials. Due to the varied sorts of toys samples, two types of sample preparation techniques were employed. Some toys were dried ash in the furnace before digestion, while others were digested straight to remove paint colors and coating. Both methods were previously reported in the literature (Hillyer, Finch et al. 2014, Mohammed, Dial et al. 2020)

Dry Ashing Method also reported (Kumar and Pastore 2007, Omolaoye, Uzairu et al. 2010, Mohammed, Dial et al. 2020) in literature was used, Toys samples were cut into small pieces and weighed into porcelain crucibles, then charred on a hot plate until fuming stopped. This was followed by 4 hours of total ashing in a muffle furnace at $350^{\circ} \mathrm{C}$ and then placing the crucible in a desiccator. After cooling the crucible, the sample was powdered and homogenized, and $1 \mathrm{gm}$ of powdered material was precisely weighted. High purity grade Nitric acid (HNO3) (65\%) and hydrogen peroxide ( $\mathrm{H} 2 \mathrm{O} 2)(30 \%)$ were added and digested. Following completion of digestion, the clear solution was cool and filtered using a Whatman 40 filter paper then made up of deionized water in a $100 \mathrm{ml}$ volumetric flask. All Digested Toys samples were kept at $40 \mathrm{C}$ until metals analysis.

To remove the paints and coatings from the toy samples, the same techniques as described in (Hillyer, Finch et al. 2014, Finch, Hillyer et al. 2015) were used. The toy sample was placed in a beaker, HNO3 was added, and the sample was gently dipped in it. A beaker solution containing a toy sample and $\mathrm{HNO} 3$ was stirred with a glass rod to help this process a tiny quantity of $\mathrm{H} 2 \mathrm{O} 2$ was also added. After removing the coating and fully digesting the sample, the toy solution was gravity filtered and the resulting mixture is diluted to the marked with deionized water into a $100 \mathrm{ml}$ volumetric flask and kept at $40^{\circ} \mathrm{C}$ until the metals analysis. To eliminate excess liquid, the remaining undissolved solid sample was rinsed and dried in a drying oven. When an undissolved solid sample was entirely dried, the difference in mass between after and before digestion was recorded, indicating the amount of toy sample effectively digested.

Standards solution, blanks, and digested samples were analyzed at Global Environmental Lab (GEL) in Karachi, Pakistan. The Atomic Absorption Spectrophotometer (AAS-Thermo Scientific Series Model iCE 3000) was used for quantitative elemental analysis.

\section{Results And Discussion}

Comparison Of Total Metal Concentrations With The EU Directive, the Canadian, the U.S., and the BIS toy safety regulation Limits

Present research only focuses on total metals concentration (TMCs). If TMCs are exceeded in high numbers, then further bioaccessibility testing is required. TMCs results are compared with the BIS, U.S., Canadian, and EU toy safety regulation limits due to the absence of national standards for toy safety regulation in Pakistan, and there are no Pakistan standards and quality control authority guidelines, especially on toys to ensure children's safety, results of the present research were compared from other regulations available in different countries and regions are mentioned in Table 1.

The results obtained from the present research are compared with European Union (EU) Toy Safety Directive (European Council 2009). In the first stage, EU limits have been used in discussion and interpretation because the EU Toy Safety Directive delivers a more comprehensive approach to the chemical safety of toys than any other regulations. After all, it differentiates the migratable limits for various types or groups of toys, namely scraped off toy material; liquid or sticky toy material; and dry, brittle, powder-like, or pliable toy material. In order to compare the TMCs, the EU limits for scraped-off toy material have been used. 
Like the United States, Consumer Product Safety Commission (U.S.CPSC) adopted the American society for testing and materials (ASTM) standard for toy safety F963-11. According to ASTM F963, 100mg/kg (total) Pb limits for substrates in children's products and for surface coating its set $90 \mathrm{mg} / \mathrm{kg}$ (soluble) for $\mathrm{Pb}, 75 \mathrm{mg} / \mathrm{kg}$ (soluble) of surface coating and substrates other than clay for Cd and $60 \mathrm{mg} / \mathrm{kg}$ (soluble) in surface coating and substrates for Cr (ASTM International 2017)

In Canada (Government of Canada,2016) sets limits for Pb in comsumer products or surface coating(soluble) $90 \mathrm{mg} / \mathrm{kg}(\mathrm{total})$ and for Cd its $1000 \mathrm{mg} / \mathrm{kg}$ in surface coating (soluble) and $130 \mathrm{mg} / \mathrm{kg}$ (total) (Government of Canada, 2018).

In India, the Bureau of Indian Standards (BIS) is the National Standards Body of India under the Department of Consumer Affairs, Ministry of Consumer Affairs, Food \& Public Distribution, Government of India. It is a statutory body established under the Bureau of Indian Standards Act, 2016. One of the main functions of BIS is to prescribe standards for covering goods and systems under the BIS regime. BIS IS:9873 regulations governing heavy metals in children's toys and set limits for $\mathrm{Cd}$ is $75 \mathrm{mg} / \mathrm{kg}, \mathrm{Pb} 90 \mathrm{mg} / \mathrm{kg}$, and $\mathrm{Cr} 60 \mathrm{mg} / \mathrm{kg}$. BIS limits are identical to U.S. limits.

In Pakistan, to the author's knowledge, this is the first scientific investigation design that evaluates the presence of toxic contaminations in low-priced children's plastic toys randomly collected from the local markets of Karachi. However, several studies have been investigated to prove heavy metals present in children's toys. Like (Kumar and Pastore 2007) found Pb and Cd in soft toys, (Godoi, Santos Jr et al. 2009) evaluated $\mathrm{Ba}, \mathrm{Cd}, \mathrm{Pb}$, and $\mathrm{Cr}$ levels in the toy by using Laser-induced breakdown spectroscopy, (Greenway and Gerstenberger 2010) examined $\mathrm{Pb}$ level in daycares centers toys and found $\mathrm{Pb}$ in excess quantities, (Omolaoye, Uzairu et al. 2010) reported the levels of $\mathrm{Pb}, \mathrm{Cd}, \mathrm{Ni}$, $\mathrm{Cr}$, Cu, $\mathrm{Zn}$, $\mathrm{Co}$, and $\mathrm{Mn}$ in PVC and Non-PVC toys and high levels were obtained in PVC toys, (Sindiku and Osibanjo 2011) research indicated that Pb, $\mathrm{Cr}$, $\mathrm{Ni}$, and $\mathrm{Cd}$ found in high quantities in plastic toys, (Ahmad, Nasibullah et al. 2012) found levels of Pb, $\mathrm{Cr}, \mathrm{Cd}, \mathrm{Co}, \mathrm{Zn}, \mathrm{Ni}$, and Mn in toys.(Guney and Zagury 2013) examined different toy categories for 10 elements and reported $\mathrm{Pb}$, $\mathrm{Cu}$, and $\mathrm{Cd}$ in high Concentration along with $\mathrm{Sb}$, Sc, Ba, $\mathrm{Cr}, \mathrm{Ni}, \mathrm{Mn}$, and As were within the limits in some categories, (Hillyer, Finch et al. 2014) also reported Pb, Cd and As in toys, (Kang and Zhu 2015) Investigated $\mathrm{Pb}$ contained in based material of plastic toys, (Turner 2018) analyzed $\mathrm{As}, \mathrm{Pb}, \mathrm{Ba}, \mathrm{Hg}$, Sb, $\mathrm{Cr}$ and $\mathrm{Cd}$ in $\mathrm{Second}$-hand toys and found $\mathrm{Pb}$ and $\mathrm{Cd}$ exceeded in limits, (Issa and Alshatteri 2019) also investigated second-hand children's product and high amount of $\mathrm{Zn}$, $\mathrm{Pb}, \mathrm{Hg}$, and $\mathrm{Cr}$ detected and (Mohammed, Dial et al. 2020) also worked on children's toys to analyzed Pb, $\mathrm{Cr}, \mathrm{Mn}, \mathrm{Cu}, \mathrm{Ni}, \mathrm{and} \mathrm{Cd}$. All former literature indicated that toxic substance in children's items are in great concerned and investigated time to time. Past pieces of literature also indicated that $\mathrm{Pb}$ and $\mathrm{Cd}$ are highly dangerous for children health and are neurotoxin and nephrotoxin that's why $\mathrm{Pb}$ and $\mathrm{Cd}$ are the prime focus of present research and $\mathrm{Cr}, \mathrm{Ni}, \mathrm{Zn}, \mathrm{Cu}$, and $\mathrm{Mn}$ are the secondary focus but equally important.

TMCs were detected in the present research are shown in Table 2 and 3 for DCT and DPCT groups and their minimum and maximum ranges are presented in Figure 1 and evaluated in Table 4. Health hazardous metals $\mathrm{Pb}, \mathrm{Cd}, \mathrm{Ni}, \mathrm{Cr}, \mathrm{Zn}, \mathrm{Cu}$, and $\mathrm{Mn}$ were found in all toys samples which are illustrated in Figure 1, it should be noted that not all elements found in this research were exceeded from regulatory limits but were present in some quantities. Seven metals were investigated however, only Pb, Cd, Ni, and Cr were exceeded from EU toy safety Regulatory limits in Table 1. Pb was detected in high quantity, In total $64 \%$ of samples exceeded from EU limits at a mean concentration of $292 \mathrm{mg} / \mathrm{kg}$ are summarized in Table 4 and presented in Figure 2a. 28 out of 44 samples had levels higher than EU limits and the remaining samples were also contained Pb but their concentrations were within the permissible limits. The highest level of Pb was detected in Painted car 4 (DPCT14) $1191 \mathrm{mg} / \mathrm{kg}$, Crocodile (DCT07) 1111 mg/kg, Purple car2 (DPCT01) 1011mg/kg, Elephant (DCT03) $981 \mathrm{mg} / \mathrm{kg}$, which is indicated that both groups of toys contained an extremely high level of $\mathrm{Pb}$ contents. Low-priced samples lead to low-quality material due to which contamination risk is also very high. For Pb, Similar results were also reported in the literature (Decharat, Maneelo et al. 2013, Hillyer, Finch et al. 2014, Kang and Zhu 2015, Turner 2018, Issa and Alshatteri 2019). Pb is used as stabilizers, coloring agents, lead(II)chromate, lead(II)carbonate, lead oxides, and lead molybdates used to produce color pigments (Ismail, Mohamad et al. 2017, O'Connor, Hou et al. 2018, Njati and Maguta 2019), basic $\mathrm{Pb}$ salts are commonly used as thermal stabilizers to enhance material properties and to reduced material costs like fillers in plastic manufacturing and molding process (Al-Qutob, Asafra et al. 2014, Njati and Maguta 2019). Above all, Recycle plastics are also one of the great sources of toxic contaminations, especially those obtained from electronic waste.

Cd was also detected in high quantity, In total $45 \%$ of samples exceeded from EU limits at a mean concentration of $63.24 \mathrm{mg} / \mathrm{kg}$ are summarized in Table 4 and presented in Figure 2a. 20 out of 44 samples had levels higher than EU limits, and the remaining samples were also contained Cd, but their concentrations were within the permissible limits. The highest level of Cd was detected in Lion (DCT11) 459mg/kg, Blue star (DCT13) $426.1 \mathrm{mg} / \mathrm{kg}$, Horse (DCT02) $397.7 \mathrm{mg} / \mathrm{kg}$, Lion (DPCT15) $111 \mathrm{mg} / \mathrm{kg}$, which is indicated that mostly DCT samples contained more Cd than DPCT, likewise Cd based pigments are also used to color plastic material and work as a stabilizer in PVC together with the salt of $\mathrm{Pb}$ and $\mathrm{Ba}$ (Turner 2019). Many pieces of literature have also been reported for Cd Contamination in Toys and baby items included; (Kumar and Pastore 2007, Omolaoye, Uzairu et al. 2010, Guney and Zagury 2012, Guney and Zagury 2013, Al-Qutob, Asafra et al. 2014).

$\mathrm{Cr}$ and $\mathrm{Ni}$ were also found in exceeded levels, but as compared to $\mathrm{Pb}$ and $\mathrm{Cd}$ their quantities were less in numbers and only $5 \% \mathrm{Cr}$ and $2 \% \mathrm{Ni}$ exceeded from EU Limits at a mean concentration of $244 \mathrm{mg} / \mathrm{kg}$ and $362 \mathrm{mg} / \mathrm{kg}$ are summarized in Table 4 and presented in Figure $2 \mathrm{a}$. out of

Page 5/16 
44 only 2 samples for $\mathrm{Cr}$ and only 1 sample for Ni exceeded from EU Limits. Cr exceeded in samples included Elephant (DCT03) 561mg/kg and Crocodile (DCT07) $479 \mathrm{mg} / \mathrm{kg}$, both of these samples were also contaminated from the high amount of $\mathrm{Pb}$ and $\mathrm{Cd}$ and also contains low levels of $\mathrm{Zn}, \mathrm{Ni}, \mathrm{Cu}$, and $\mathrm{Mn}$ as $\mathrm{Cr}$ are also used in pigments $\mathrm{Cr}(\mathrm{VI})$ as the brightly colored yellow pigment of PbCrO4 (Turner 2018$)$. Ni only exceeded in 1 sample in the highest quantity that is Study boy (DCT08) 3000.1 mg/kg however in that sample Pb and Cd were not detected although other elements $\mathrm{Zn}, \mathrm{Cr}, \mathrm{Mn}$, and Cu were detected in lesser quantities. Series of experiments in past literature indicated low levels of contaminations also detected in toys that are (Leal, Catarino et al. 2016, Sobhanardakani and Babaei 2016, Karaś and Frankowski 2018, Al Kindi and Ali 2020, Mohammed, Dial et al. 2020) on the other hand in most literature levels of $\mathrm{Zn}, \mathrm{Cr}, \mathrm{Ni}, \mathrm{Cu}, \mathrm{Mn}$ were reported in high quantities (Al-Qutob, Asafra et al. 2014, Ismail, Mohamad et al. 2017).

TMCs results were also compared with the U.S., Canadian, and BIS Regulations are shown in Table 1. BIS and U.S. limits are identical and are shown in similar results in Table 4 and combine represented in Figure $2 \mathrm{~b}$. In this case, Cr was higher in numbers, as In total $45 \%$ of samples were exceeded U.S. limits as well as BIS limits. 20 out of 44 samples showed a higher $\mathrm{Cr}$ level concerning U.S. and BIS. For Pb, $30 \%$ of samples exceeded and for $\mathrm{Cd}$ only $16 \%$ exceeded from respected limits. 13 toys for $\mathrm{Pb}$ and 7 toys for Cd were exceeded out of 44 samples in total, and for Canadian limits; $30 \%$ of samples contained $\mathrm{Pb}$ levels were above the total or soluble limit, 13 toys samples out of 44 exceeded. For Cd soluble limits, not a single sample exceeded Canadian limits.

In Figure 2a-2b, If we compared toy safety regulations limits with TMCs, it shows that more samples contain Pb and Cd from EU Limits as compared to BIS, U.S., and Canadian limits. However, concerning BIS and U.S. limits more samples contain $\mathrm{Cr}$ as $\mathrm{Cr}$ has in higher percentage shows in Figure 2b and a lower percentage in Figure 2a. In another word, the number of toys samples comparing with $\mathrm{EU}$ limit $\mathrm{Pb}>\mathrm{Cd}>\mathrm{Cr}>\mathrm{Ni}$ pattern observed Alternatively, by comparing with U.S. and BIS limits $\mathrm{Cr}>\mathrm{Pb}>\mathrm{Cd}$ pattern observed for the number of samples.

Figure 3 concludes a total number of toys samples Exceeded from toxic levels concerning EU limits of toy safety regulations which are the most comprehensive regulation in all. Total samples $(n=44)$ had analyzed for toxic contamination, purchased from different sites of Karachi indicated that's 28 samples for Pb, 20 samples for $\mathrm{Cd}, 2$ samples for $\mathrm{Cr}$, and only 1 sample for Ni exceeded from EU limits of scraped-off toy materials, but it should be noted that all 44 samples contain some amounts of $\mathrm{Zn}, \mathrm{Cu}, \mathrm{Mn}, \mathrm{Pb}, \mathrm{Cr}, \mathrm{Cd}$, and Ni. However, their levels had not crossed the permissible limits.

\section{Total Metal Concentrations in low-priced plastics toys (DCT)}

DCT group contains 23 toys samples are presented in Table 2 and summarized in Table 5a. samples were coded as DCT01-DCT23, digestion was performed by using the dry ashing method as reported in (Kumar and Pastore 2007, Omolaoye, Uzairu et al. 2010, Mohammed, Dial et al. 2020) and analyzed by atomic absorption spectrophotometer at Global Environmental Lab in Karachi, Pakistan.

The majority of the toys samples in the DCT group contain high levels of contamination. Overall, results were compared with different toy safety regulation limits are summarized in Table $1.83 \%$ of toys samples, 19 out of 23 were exceeded from EU limits of scraped-off toy material for $\mathrm{Pb}, 65 \%$ samples 15 out of 23 toys for $\mathrm{Cd}, 9 \%$ samples 2 out of 23 toys for $\mathrm{Cr}$ and $4 \%$ of toy 1 out of 23 toy samples for nickel were also exceeded from EU limits are summarized in Table $5 \mathrm{a}$ and represented in Figure $4 \mathrm{a}$. The TMCs of Zn, Mn, and Cu were also detected but levels were within the EU limits. For Pb, the results of DCT03, DCT05, DCT07, and DCT18 were extremely higher in numbers. for Cd, DCT02, DCT11, and DCT13 were extremely high. For Cr, DCT03, and DCT07 and for Ni, only DCT08 was extremely higher than allowable scrap-off materials limits set by EU-Derivative. In DCT average values for Pb 205.33mg/kg, Cd 85.64mg/kg, Ni 225.92mg/kg, Cr 153.17mg/kg, Zn $220.93 \mathrm{mg} / \mathrm{kg}, \mathrm{Mn} 894.78 \mathrm{mg} / \mathrm{kg}$ and $\mathrm{Cu} 135.66 \mathrm{mg} / \mathrm{kg}$ clearly indicated metals existence in toys samples are shown in Table $5 \mathrm{a}$. contamination levels in the DCT group were summarized in pattern as $\mathrm{Pb}>\mathrm{Cd}>\mathrm{Cr}>\mathrm{Ni}$.

On the other hand, when comparing DCT results from U.S. and BIS toy safety regulation Limits Table 1. it is notable that $26 \%$ of toys, 6 out of 23 were higher from U.S. and BIS limits for $\mathrm{Pb}, 22 \%$ of toys 3 out of 23 for $\mathrm{Cd}$ and $48 \%$ of toys 11 out of 23 were higher for $\mathrm{Cr}$ are summarized in Table 5a and represent in Figure 4b. compared to EU limits with U.S. and BIS limits results Figure 4a-4b indicates that level of Pb and Cd level was much higher in no of toys as compared to U.S. and BIS, however, Cr levels were high in no of toys with respect to U.S. and BIS and low in no of toys with respect to EU limits as shown in Figure 4a-4b. In brief, for EU limits $\mathrm{Pb}>\mathrm{Cd}>\mathrm{Cr}>\mathrm{Ni}>\mathrm{Othermetals}$ and for U.S. and BIS $\mathrm{Cr}>\mathrm{Pb}>\mathrm{Cd}>$ othermetals patterns were observed. Meanwhile, by comparing the results from the Canadian Limits similar pattern was also observed for Pb but Cd levels were not exceeded from Canadian limits.

\section{Total Metal Concentrations in low-priced plastics toys with paint or coating (DPCT)}

DPCT group contains 21 toys samples are presented in Table 3 and summarized in Table 5b. samples were coded as DPCT01-DPCT21. Digestion was performed as reported in (Hillyer, Finch et al. 2014, Finch, Hillyer et al. 2015). 43\% of painted toys sample 9 out of 21 for Pb and $24 \%$ samples 5 out of 21 for Cd were exceeded from EU limits for Scraped off toy materials limit are shown in Figure 5a. Ni, Cr, Zn, Cu, and Mn 
were also detected but levels were within the EU limits. As compared to DCT fewer levels of contamination were observed in DPCT only Pb and $\mathrm{Cd}$ were exceeded in number but not a single sample was exceeded for $\mathrm{Cr}$ and $\mathrm{Ni}$. In the same way, no $\mathrm{Zn}, \mathrm{Cu}$, and $\mathrm{Mn}$ were detected above the EU limits in DPCT. One of the reasons is that as $\mathrm{Pb}, \mathrm{Cd}, \mathrm{Cr}$, Ni, and many metals are used as pigments and stabilizers in paints production (O'Connor, Hou et al. 2018, Al Kindi and Ali 2020). but toys without coatings like DCT group where more contaminations are possible due to the presence of inner matrices like filler and catalyst (Turner 2019, Al Kindi and Ali 2020, Aurisano, Huang et al. 2020) Higher results were shown for Pb in samples included DPCT01, DPCT07, DPCT11, DPCT12, DPCT14, and DPCT15, And for Cd in DPCT03, DPCT04, DPCT11, DPCT15, and DPCT16 showed the highest levels. Average values of TMCs in DPCT group for Pb 263.39mg/kg, Cd 17.86mg/kg, Ni 98.33mg/kg, Cr $65.61 \mathrm{mg} / \mathrm{kg}, \mathrm{Zn} 259.75 \mathrm{mg} / \mathrm{kg}, \mathrm{Mn} 541.90 \mathrm{mg} / \mathrm{kg}$ and $\mathrm{Cu} 118.56 \mathrm{mg} / \mathrm{kg}$ indicated the existence of metals in painted toys. As a pattern for toxic contamination in DPCT with respect to EU limits drawn only $\mathrm{Pb}$ and $\mathrm{Cd}$ were observed $\mathrm{Pb}>\mathrm{Cd}>$ other metals.

The results compared with U.S. and BIS toy safety regulation Limits are shown in Table 1 it is indicated that $33 \%$ of paint-coated toys (7 out of 21) for $\mathrm{Pb}, 43 \%$ (9 out of 21) for $\mathrm{Cr}$, and $9 \%$ (2 out of 21) painted toys samples were Exceeded are represented in Figure $5 \mathrm{~b}$. A similar pattern of results was observed for $\mathrm{Pb}$ where $33 \%$ of $\mathrm{Pb}$, in $\mathrm{DPCT}$ were exceeded Canadian limits, and 7 out of 21 toys samples exceeding from Canadian limits. By comparing no of samples from EU, BIS, U.S. and Canadian limits are shown in Figure 5a-5b summarized that with respect to EU, Pb was dominant in no of samples but with respect to U.S. and BIS limits $\mathrm{Cr}$ was dominant in no of samples. In brief, for EU limits Pb $>\mathrm{Cd}>$ othermetals whereas for U.S. and BIS limit $\mathrm{Cr}>\mathrm{Pb}>\mathrm{Cd}>$ othermetals patterns were observed.

\section{Conclusion}

Forty-four samples, including 23 plastic toys and 21 plastic toys containing paint or coating samples were selected and purchased from different local markets in Karachi, Pakistan. Collecting those plastic toys which were low priced, designed for small children around 3-5 years old and mostly demanded too low-income groups. All samples analyzed in the present research were grouped into two categories: children's plastic toys (DCT) and children's plastic toys with paint or coating (DPCT) and tested for $\mathrm{Pb}, \mathrm{Cd}, \mathrm{Ni}, \mathrm{Zn}, \mathrm{Cr}, \mathrm{Cu}$, and $\mathrm{Mn}$ contaminations in term of total metal concentration (TMCs). To the author's knowledge, this is the first scientific research design in Pakistan that assesses the presence of toxic metals contamination in children's plastic toys. However, there are no Pakistan standards and quality control authority guidelines, especially on toys to ensure children's safety in Pakistan. Therefore, Obtained results were compared from other regulations available in different countries and regions. Initially, results were compared with EU Toy Safety Regulation limits because the EU provide a more comprehensive approach and categorized toys into different groups. Pb and Cd are known as poisons, neurotoxins, and nephrotoxins that's why both metals are the main focus of present research. Results revealed that children's toys that are present in Karachi local markets contain high levels of $\mathrm{Pb}, \mathrm{Cd}, \mathrm{Ni}$, and $\mathrm{Cr}$ and minors levels of $\mathrm{Zn}, \mathrm{Cu}$, and $\mathrm{Mn}$. In the DCT group, 83\% Pb and 65\% Cd were reported. However, In the DPCT group levels of $43 \% \mathrm{~Pb}$ and $24 \% \mathrm{Cd}$ were detected low as compared to DCT. Overall, toys samples contain $64 \% \mathrm{~Pb}, 45 \% \mathrm{Cd}, 5 \% \mathrm{Cr}$, and $2 \% \mathrm{Ni}$. Low priced items are easily available in local markets because of the lack of regulation and restrictions from check and balance system these contaminated toys are easily entering the markets but investigations reveal that these toys are highly dangerous for children's health and may cause serious health issues and damage to their brain, kidney, bones and nervous systems, even small amount in the blood may affect child's health so badly that's why Future studies could fruitfully explore this issue further in children's toys.

\section{Declarations}

Ethics approval Not applicable.

Consent to participate Not applicable.

Consent for publication Not applicable.

Availability of Data and materials All data generated or analysed during this study are included in this published article and its supplementary information files.

Competing interests The authors' declare that they have no competing interests.

Funding No funding was provided by the university or any other agency.

\section{Author's Contributions}

This work was carried out in collaboration between Department of Chemistry, (University of Karachi) and Globel Environmental Lab (pvt) Limited. Authors DSG and AKT managed the literature searches. Sampling strategy, collection, sorting, investigation and samples preparation were performed by DSG and AG. Elemental analysis was performed by MAM. Statistical analysis, interpretation, calculations and editing were 
performend by AG and DSG under the assistance of TA. The first draft of the manuscript were written by DSG and AG, later on revised by AKT and TA. DSG completed his M.Phil. degree from UOK under the supervision of AKT. All authors read and approved the final manuscript.

Acknowledgements The authors would like to thanks Global Environmental Lab (Pvt) Ltd. for analyzing samples in this research work.

\section{References}

Ahmad, N., M. Nasibullah, F. Hassan, A. Singh, D. Patel, A. Khan and M. Rahman (2012). "Heavy metal assessment of leachates of some plastic toys purchased from different districts of UP, India." Int. Res. J. Environ. Sci. 1: 32-36.

Al-Qutob, M., A. Asafra, T. Nashashibi and A. A. Qutob (2014). "Determination of different trace heavy metals in children's plastic toys imported to the West Bank/Palestine by ICP/MS-environmental and health aspects." Journal of Environmental Protection 5(12): 1104.

Al Kindi, G. and Z. Ali (2020). "Lead, Nickel and Cadmium in the coating of children's toys effects and influencing factors." MS\&E 737(1): 012186.

ASTM International (American Society for Testing and Materials), 2017. Standard Consumer Safety Specification for Toy Safety. Designation: F963-17; West Conshohocken, PA, USA.

Aurisano, N., L. Huang, L. M. i Canals, O. Jolliet and P. Fantke (2020). "Chemicals of concern in plastic toys." Environment International 146: 106194.

Becker, M., S. Edwards and R. I. Massey (2010). Toxic chemicals in toys and children's products: limitations of current responses and recommendations for government and industry. Environmental Science \& Technology 44(21): 7986-7991. https://doi.org/10.1021/es1009407

Brewer, G. J. (2010). "Risks of Copper and Iron Toxicity during Aging in Humans." Chemical Research in Toxicology 23(2): 319-326.

Bureau of Indian Standards (1999) Indian standard safety requirement for toys, part 3, Migration of certain elements (Ist revision). IS: 9873 (Part 3).

Charehsaz, M., D. GÜVEN, A. BAKANOĞLU, H. CELIK, R. CEYHAN, D. D. EROL and A. AYDIN (2014). "Lead, cadmium, arsenic, and nickel content of toy samples marketed in Turkey." Turk. J. Pharm. Sci 11(3): 263-268.

Cui, X.-Y., S.-W. Li, S.-J. Zhang, Y.-Y. Fan and L. Q. Ma (2015). "Toxic metals in children's toys and jewelry: coupling bioaccessibility with risk assessment." Environmental pollution 200: 77-84.

Decharat, S., S. Maneelo and S. Chuchay (2013). "Assessment of lead levels in some children's plastic toys." Asia-Pacific Journal of Science and Technology. 18(6): 1026-1033.

European Council, 2019. Directive 2009/48/EC of the European Parliament and of the Council on the Safety of Toys (Latest Consolidated Version: 18/11/2019). https://eur-lex.europa.eu/legal-content/EN/TXT/?uri=CELEX:02009L0048- 20191118.

Finch, L. E., M. M. Hillyer and M. C. Leopold (2015). "Quantitative analysis of heavy metals in children's toys and jewelry: a multi-instrument, multitechnique exercise in analytical chemistry and public health." Journal of chemical education 92(5): 849-854.

Godoi, Q., D. Santos Jr, L. C. Nunes, F. O. Leme, I. A. Rufini, J. A. Agnelli, L. C. Trevizan and F. J. Krug (2009). "Preliminary studies of laserinduced breakdown spectrometry for the determination of Ba, Cd, Cr and Pb in toys." Spectrochimica Acta Part B: Atomic Spectroscopy $64(6)$ : 573-581.

Government of Canada, 2010a. Canada Consumer Product Safety Act (CCPSA). http://laws-lois.justice.gc.ca/eng/acts/C-1.68/index.html. Government of Canada, 2011. Toys Regulations (SOR/2011-17). https://laws-lois. justice.gc.ca/eng/regulations/SOR-2011-17/index.html. Government of Canada, 2016. Surface Coating Materials Regulations (SOR/2016- 193). https://laws-lois.justice.gc.ca/eng/regulations/SOR2016-193/page-1. html\#h-832987.

Government of Canada, 2018a. Consumer Products Containing Lead Regulations (SOR/2018-83). https://lawslois.justice.gc.ca/eng/regulations/SOR-2018-83/ page-1.html\#h-859295.

Government of Canada, 2018b. Children's Jewellery Regulations (SOR/2018-82). https://laws-lois.justice.gc.ca/eng/regulations/SOR-201882/page-1.html. 
Greenway, J. A. and S. Gerstenberger (2010). "An evaluation of lead contamination in plastic toys collected from day care centers in the Las Vegas Valley, Nevada, USA." Bulletin of environmental contamination and toxicology 85(4): 363-366.

Guney, M., S. Kismelyeva, Z. Akimzhanova and K. Beisova (2020). "Potentially toxic elements in toys and children's jewelry: A critical review of recent advances in legislation and in scientific research." Environmental Pollution: 114627.

Guney, M. and G. J. Zagury (2012). "Heavy metals in toys and low-cost jewelry: critical review of US and Canadian legislations and recommendations for testing." Environmental science \& technology. 46(8): 4265-4274.

Guney, M. and G. J. Zagury (2013). "Contamination by ten harmful elements in toys and children's jewelry bought on the North American market." Environmental science \& technology 47(11): 5921-5930.

Guney, M. and G. J. Zagury (2014). "Bioaccessibility of As, Cd, Cu, Ni, Pb, and Sb in toys and low-cost jewelry." Environmental science \& technology 48(2): 1238-1246.

Guney, M. and G. J. Zagury (2014). "Children's exposure to harmful elements in toys and low-cost jewelry: characterizing risks and developing a comprehensive approach." Journal of hazardous materials 271: 321-330.

Hillyer, M. M., L. E. Finch, A. S. Cerel, J. D. Dattelbaum and M. C. Leopold (2014). "Multi-technique quantitative analysis and socioeconomic considerations of lead, cadmium, and arsenic in children's toys and toy jewelry." Chemosphere 108: 205-213.

Ismail, S. N. S., N. S. Mohamad, K. Karuppiah, E. Z. Abidin, I. Rasdi and S. M. Praveena (2017). "Heavy metals content in low-priced toys." JEAS 5: 1499-1509.

Issa, H. M. and A. H. Alshatteri (2019). "Second-Hand Infant Care Plastic Products Sold in Markets of Kalar City, Kurdistan Region, Iraq: Heavy Metals Contamination and Risk Assessment." Journal of Garmian University 6(SCAPAS Conferance): 8-17.

Kang, S. and J. Zhu (2015). "Total lead content and its bioaccessibility in base materials of low-cost plastic toys bought on the Beijing market." Journal of Material Cycles and Waste Management 17(1): 63-71.

Kang, S. G. and J. X. Zhu (2014). Metals contamination and leaching potential in plastic toys bought on the Beijing market. Advanced Materials Research, Trans Tech Publ.

Karaś, K. and M. Frankowski (2018). "Analysis of hazardous elements in children toys: Multi-elemental determination by chromatography and spectrometry methods." Molecules 23(11): 3017.

Kumar, A. and P. Pastore (2007). "Lead and cadmium in soft plastic toys." Current Science 93(6): 818-822.

Kumar Das, S., A. singh Grewal and M. Banerjee (2011). "A BRIEF REVIEW: HEAVY METAL AND THEIR ANALYSIS." Organization $11(1)$ : 003.

Le ha, V. o. t. h. i., Linh, T. T. T., Huong, N. T. T., \& Chung, N. T. (2017). "Study on Heavy Metal Speciation and Health Implication from Plastic Toys in Hanoi, Vietnam." International Journal of Innovative Studies in Sciences and Engineering_Technology_(IJISSET)_3(9): 11-16.

Leal, M. F. C., R. I. Catarino, A. M. Pimenta, M. R. S. Souto, C. S. Afonso and A. F. Fernandes (2016). "Lead migration from toys by anodic stripping voltammetry using a bismuth film electrode." Archives of environmental \& occupational health 71(5): $300-306$.

Mohammed, T., D. Dial, D. Maharaj, C. Smith, N. Persad, S. Mohammed and A. Mohammed (2020). "Heavy metals in childrens toys and baby items commonly sold in Trinidad and Tobago." Journal of Environmental Chemistry and Ecotoxicology. 12(1): 59-64.

Negev, M., T. Berman, S. Reicher, M. Sadeh, R. Ardi and Y. Shammai (2018). "Concentrations of trace metals, phthalates, bisphenol A and flameretardants in toys and other children's products in Israel." Chemosphere 192: 217-224.

Njati, S. Y. and M. M. Maguta (2019). "Lead-based paints and children's PVC toys are potential sources of domestic lead poisoning-A review." Environmental pollution.

O'Connor, D., D. Hou, J. Ye, Y. Zhang, Y. S. Ok, Y. Song, F. Coulon, T. Peng and L. Tian (2018). "Lead-based paint remains a major public health concern: A critical review of global production, trade, use, exposure, health risk, and implications." Environment international 121: 85-101.

Omolaoye, J., A. Uzairu and C. Gimba (2010). "Heavy metal assessment of some soft plastic toys imported into Nigeria from China." Journal of Environmental chemistry and Ecotoxicology 2(8): 126-130.

Page 9/16 
Ozbek, N., G. S. Ustabasi and S. Akman (2015). "Direct determination of lead in plastic toys by solid sampling high resolution-continuum source graphite furnace atomic absorption spectrometry." Journal of Analytical Atomic Spectrometry. 30(8): 1782-1786.

Ratnakumar, A., A. De Alwis and S. Adikary (2017). Investigation of the Presence of Heavy Metals in Plastic Toys Available in Sri Lankan Market. Proceedings of International Forestry and Environment Symposium.

Sindiku, O. and O. Osibanjo (2011). "Some priority heavy metals in children toys imported to Nigeria." Journal of Toxicology and Environmental Health Sciences 3(4): 109-115.

Sobhanardakani, S. and B. Babaei (2016). "Determination of Heavy Metals Contamination in Children's Toys Marketed in Hamadan City in 2015." Journal of Research in Environmental Health 2(2): 165-172.

Turner, A. (2018). "Concentrations and Migratabilities of Hazardous Elements in Second-Hand Children's Plastic toys." Environmental science \& technology 52(5): 3110-3116.

Turner, A. (2019). "Cadmium pigments in consumer products and their health risks." Science of The Total Environment 657: $1409-1418$.

Yang, F. and I. Y. Massey (2019). "Exposure routes and health effects of heavy metals on children." BioMetals: 1-11.

\section{Tables}

Table 1. Toy safety regulations limits according to EU (Europen Council 2009), USA (U.S.CPSC) (ASTM International 2017), Canada (Government of Canada 2011,2018), and BIS (Bureau of Indian Standard 1999).

\begin{tabular}{|c|c|c|c|c|c|c|c|c|c|c|}
\hline \multirow[t]{2}{*}{$\begin{array}{l}\text { Heavy } \\
\text { Metals }\end{array}$} & \multicolumn{3}{|c|}{$\begin{array}{l}\text { EU migratable limits } \\
(\mathrm{mg} / \mathrm{kg})\end{array}$} & \multicolumn{3}{|c|}{$\begin{array}{l}\text { USA(U.S.CPSC) } \\
(\mathrm{mg} / \mathrm{kg})\end{array}$} & \multicolumn{3}{|l|}{$\begin{array}{l}\text { Canada } \\
(\mathrm{mg} / \mathrm{kg})\end{array}$} & \multirow[t]{2}{*}{$\begin{array}{l}\text { BIS } \\
(1999) \\
(\mathrm{mg} / \mathrm{kg})\end{array}$} \\
\hline & $\begin{array}{l}\text { Liquid } \\
\text { or } \\
\text { sticky } \\
\text { toy } \\
\text { material }\end{array}$ & $\begin{array}{l}\text { Scraped- } \\
\text { off toy } \\
\text { material }\end{array}$ & $\begin{array}{l}\text { Dry,brittle, } \\
\text { powder- } \\
\text { like or } \\
\text { pliable } \\
\text { material }\end{array}$ & $\begin{array}{l}\text { Children's } \\
\text { products }\end{array}$ & $\begin{array}{l}\text { Surface } \\
\text { coatings } \\
\text { and } \\
\text { substrates } \\
\text { other than } \\
\text { modeling } \\
\text { clay } \\
\text { included } \\
\text { as part of } \\
\text { a toy } \\
\text { (soluble) }\end{array}$ & $\begin{array}{l}\text { Modeling } \\
\text { calys } \\
\text { included } \\
\text { as a part } \\
\text { of a toy } \\
\text { (soluble) }\end{array}$ & Jewelry(total) & $\begin{array}{l}\text { Surface } \\
\text { coating } \\
\text { material } \\
\text { in toys } \\
\text { (soluble) }\end{array}$ & $\begin{array}{l}\text { Consumer } \\
\text { products }\end{array}$ & \\
\hline $\mathrm{Pb}$ & 0.5 & 23 & 2 & 100 (total) & 90 & 90 & 90 & 90 & 90(total) & 90 \\
\hline $\mathrm{Cd}$ & 0.3 & 17 & 1.3 & 200ug & 75 & 50 & - & 1000 & 130 & 75 \\
\hline $\mathrm{Cr}$ & 9.4 & 460 & 37.5 & - & 60 & 25 & - & - & - & 60 \\
\hline $\mathrm{Ni}$ & 18.8 & 930 & 75 & - & - & - & - & - & - & - \\
\hline $\mathrm{Cu}$ & 156 & 7700 & 622.5 & - & - & - & - & - & - & - \\
\hline $\mathrm{Zn}$ & 938 & 46000 & 3750 & - & - & - & - & - & - & - \\
\hline $\mathrm{Mn}$ & 300 & 15000 & 1200 & - & - & - & - & - & - & - \\
\hline
\end{tabular}

Table 2. Concentrations (mg/kg) of heavy metals in low-priced children's plastics toys (DCT). 


\begin{tabular}{|c|c|c|c|c|c|c|c|c|c|}
\hline No. & Sample Code & Description & $\mathrm{Pb}$ & Cd & $\mathrm{Ni}$ & $\mathrm{Cr}$ & $\mathrm{Zn}$ & Mn & $\mathrm{Cu}$ \\
\hline & & EU-Limit (Scraped-off toy material) mg/kg & 23 & 17 & 930 & 460 & 46,000 & 15,000 & 7700 \\
\hline 1 & DCT01 & Small baby boy & 191 & 69 & 161 & 321 & 50.1 & 1871 & 311 \\
\hline 2 & DCT02 & Horse & 117.9 & 397.7 & ND & ND & 210.1 & 27.2 & 821.3 \\
\hline 3 & DCT03 & Elephant & 981 & 42 & 211 & 561 & 91 & 1111 & 109 \\
\hline 4 & DCT04 & Banana & ND & 21 & 229 & 431 & 100.5 & 972 & 121 \\
\hline 5 & DCT05 & Duck & 791 & 9.6 & 122 & 339 & 81 & 1211 & 91 \\
\hline 6 & DCT06 & Rabbit 1 & 39.6 & 7.4 & ND & ND & 677 & 17.4 & 39.8 \\
\hline 7 & DCT07 & Crocodile & 1111 & 50.1 & 412 & 479 & 111 & 3209 & 99 \\
\hline 8 & DCT08 & Study boy & ND & ND & 3000.1 & 291 & 122 & 1811 & 451 \\
\hline 9 & DCT09 & Study girl & 28.1 & 4.2 & ND & ND & 874.2 & 17.2 & 55.5 \\
\hline 10 & DCT10 & Apple & 29.3 & 59.7 & ND & ND & 74.2 & 18.2 & 59 \\
\hline 11 & DCT11 & Lion & 32.0 & 459 & ND & ND & 110.6 & 19 & 80 \\
\hline 12 & DCT12 & Pineapple & 41.5 & 36.9 & ND & ND & 82.6 & 17.6 & 42.3 \\
\hline 13 & DCT13 & Blue star & 38.1 & 426.1 & ND & ND & 98.0 & 18.2 & 43.9 \\
\hline 14 & DCT14 & Big deer & 36.1 & 10.7 & ND & ND & 1036.4 & 24.7 & 29.9 \\
\hline 15 & DCT15 & Octopus & 38.7 & 5.1 & ND & ND & 806.7 & 27.4 & 50.5 \\
\hline 16 & DCT16 & Rabbit 2 & 36.1 & 92.5 & ND & ND & 155.5 & 15.9 & 53.7 \\
\hline 17 & DCT17 & Blue ball & 39.1 & 93.4 & ND & ND & 63.9 & 24.2 & 34.8 \\
\hline 18 & DCT18 & Yellow ball & 971 & ND & 310.2 & 333 & 91 & 1921 & ND \\
\hline 19 & DCT19 & Kitty & 41 & 31 & 110.4 & 219 & 51 & 1091 & 91 \\
\hline 20 & DCT20 & Pink ball & 18.3 & 43.1 & ND & ND & 100.6 & 14 & 36.6 \\
\hline 21 & DCT21 & Green ball & 61 & ND & 320.5 & 209 & 41 & 2342 & 209 \\
\hline 22 & DCT22 & Leach fish & 81 & 61 & 129 & 111 & 21 & 3241 & 291 \\
\hline 23 & DCT23 & Camel & ND & 50.4 & 191 & 229 & 32 & 1559 & ND \\
\hline
\end{tabular}

Table 4. Descriptive statistics representation $(\mathrm{mg} / \mathrm{kg}$ ) in low-priced children's toys (DCT + DPCT $n=44)$ with percentages of total toy samples exceed from different regulations limits.

Table 5. Comparation of total metal concentrations results from different toy safety regulations limits. 


\begin{tabular}{|c|c|c|c|c|c|c|c|c|c|}
\hline No. & Sample Code & Description & $\mathrm{Pb}$ & Cd & $\mathrm{Ni}$ & $\mathrm{Cr}$ & $\mathrm{Zn}$ & Mn & $\mathrm{Cu}$ \\
\hline & & EU - Limit (Scraped-off toy material) mg/kg & 23 & 17 & 930 & 460 & 46,000 & 15,000 & 7700 \\
\hline 1 & DРCT01 & Purple car & 1011 & ND & 322 & 92 & 60.1 & 891 & 109 \\
\hline 2 & DРCT02 & White train & 0.6 & 0.6 & ND & ND & 57.5 & 3.3 & 25 \\
\hline 3 & DРCT03 & Painted car 1 & 101 & 29 & 344 & 119 & 121 & 781 & 61 \\
\hline 4 & DРCT04 & Blue ship & ND & 81 & 392 & 101 & 231 & 689 & 52 \\
\hline 5 & DPCT05 & Yellow orange hen & ND & 0.5 & ND & ND & 22.8 & 0.9 & 23 \\
\hline 6 & DРCT06 & Yellow airplane & 2.1 & 1.4 & ND & ND & 44.1 & 2.1 & 5.5 \\
\hline 7 & DРCT07 & Painted car 2 & 761 & ND & 191 & 91 & 421 & 992 & 209 \\
\hline 8 & DРCT08 & Orange duck & 1.3 & 0.4 & ND & ND & 28.9 & 2.3 & 3.0 \\
\hline 9 & DРCT09 & Pink buffalo & 3.1 & 0.3 & ND & ND & 37.9 & ND & 13.1 \\
\hline 10 & DPCT10 & Green car & 0.6 & 0.6 & ND & ND & 41.5 & 3.6 & 11.2 \\
\hline 11 & DPCT11 & White zebra & 911 & 71 & 113 & 161 & 72 & 489 & 412 \\
\hline 12 & DPCT12 & Painted car 3 & 868 & ND & 211 & 141 & 91 & 121 & ND \\
\hline 13 & DPCT13 & Eye spotted wolf & 26 & 2.5 & ND & ND & 498 & ND & 26.7 \\
\hline 14 & DPCT14 & Painted car 4 & 1191 & 09 & 122 & 251 & 109 & 981 & 81 \\
\hline 15 & DPCT15 & Lion & 611 & 111 & 219 & 211 & 111 & 99 & 89 \\
\hline 16 & DPCT16 & Silver car & 20.1 & 51 & 151 & 211 & 161 & 1161 & 61 \\
\hline 17 & DPCT17 & Painted car 5 & 23.5 & 15.1 & ND & ND & 679 & 1021 & 215.2 \\
\hline 18 & DPCT18 & Red fish & ND & ND & ND & ND & 723.4 & ND & 313.5 \\
\hline 19 & DPCT19 & Green frog & ND & 0.7 & ND & ND & 606.4 & 1390.1 & 322.4 \\
\hline 20 & DPCT20 & Orange green Turtle & ND & 0.5 & ND & ND & 673.2 & 1365.3 & 203.0 \\
\hline 21 & DPCT21 & Yellow star & ND & 0.6 & ND & ND & 665.0 & 1387.4 & 254.2 \\
\hline
\end{tabular}




\begin{tabular}{|c|c|c|c|c|c|c|c|c|c|}
\hline \multicolumn{2}{|l|}{ Heavy Metals } & $\mathrm{Pb}$ & $\mathrm{Cd}$ & $\mathrm{Cr}$ & $\mathrm{Zn}$ & $\mathrm{Cu}$ & $\mathrm{Ni}$ & & $\mathrm{Mn}$ \\
\hline \multicolumn{2}{|l|}{ Minimum } & 0.62 & 0.34 & 90 & 20 & 3.07 & 110 & & 0.96 \\
\hline \multicolumn{2}{|l|}{ Maximum } & 1190 & 459.01 & 560 & 1036.48 & 821.35 & 300 & & 3240 \\
\hline \multicolumn{2}{|l|}{ Average } & 292.68 & 63.24 & 244 & 239.06 & 136.67 & 362 & & 779.25 \\
\hline \multicolumn{2}{|l|}{ Sd } & 413.62 & 114.31 & 133.94 & 282.54 & 159.73 & 628 & & 884.54 \\
\hline \multicolumn{2}{|l|}{$\%$ RSD } & 141.31 & 180.74 & 54.89 & 118.18 & 116.87 & 173 & & 113.51 \\
\hline \multicolumn{2}{|l|}{ Total Toy ( $n=44)$ Sample Exceed From EU Limits } & $64 \%(28)$ & $45 \%(20)$ & $5 \%(2)$ & - & - & $2 \%$ & & - \\
\hline \multicolumn{2}{|l|}{ Total Toys $(n=44)$ Sample Exceed From BIS } & $30 \%(13)$ & $16 \%(7)$ & $45 \%(20)$ & - & - & - & & - \\
\hline \multicolumn{2}{|c|}{ Total Toys ( $n=44)$ Sample Exceed From U.S. CPSC limits } & $30 \%(13)$ & $16 \%(7)$ & $45 \%(20)$ & - & - & - & & - \\
\hline \multicolumn{2}{|c|}{ Total Toys ( $n=44)$ Sample Exceed From Canadian Limits } & $30 \%(13)$ & - & - & - & - & - & & - \\
\hline \multicolumn{10}{|c|}{ a) Comparation of total metal concentrations of detected metals in low-priced children's plastics toys DCT group ( $n=23$ ): } \\
\hline Detected Metals & $\mathrm{Pb}$ & Cd & $\mathrm{Ni}$ & $\mathrm{Cr}$ & $\mathrm{Zn}$ & \multicolumn{2}{|l|}{ Mn } & \multicolumn{2}{|c|}{ Cu } \\
\hline Average & 205.3391 & 85.64783 & 225.9217 & 153.1739 & 220.9304 & \multicolumn{2}{|c|}{894.7826} & \multicolumn{2}{|c|}{135.6652} \\
\hline SD & 361.2576 & 138.6225 & 617.8567 & 185.8919 & 302.278 & \multicolumn{2}{|c|}{1079.018} & \multicolumn{2}{|c|}{185.8307} \\
\hline$\%$ RSD & 175.9322 & 161.8517 & 273.4826 & 121.36 & 136.8205 & \multicolumn{2}{|c|}{120.59} & \multicolumn{2}{|c|}{136.9774} \\
\hline \%Samples Exceed from EU-Limit & $83 \%(19)$ & $65 \%(15)$ & $4 \%(1)$ & $9 \%(2)$ & - & \multicolumn{2}{|l|}{-} & \multicolumn{2}{|l|}{-} \\
\hline \%Samples Exceed from U.S. Limit & $26 \%(6)$ & $13 \%(3)$ & - & $48 \%(11)$ & - & \multicolumn{2}{|l|}{-} & \multicolumn{2}{|l|}{-} \\
\hline \%Samples Exceed from Canadian Limit & $26 \%(6)$ & - & - & - & - & \multicolumn{2}{|l|}{-} & - & \\
\hline \%Samples Exceed from BIS Limit & $26 \%(6)$ & $13 \%(3)$ & - & $48 \%(11)$ & - & - & & - & \\
\hline 2. Comparation of total metal concentr & tions of de & ected metal & in low-price & d children's p & lastics toys D & DPCT gr & $-r>$ & 21) & \\
\hline Detected Metals & $\mathrm{Pb}$ & Cd & $\mathrm{Ni}$ & $\mathrm{Cr}$ & $\mathrm{Zn}$ & Mn & & $\mathrm{Cu}$ & \\
\hline Average & 263.3952 & 17.86667 & 98.33333 & 65.61905 & 259.7524 & 541. & 048 & & 3.5619 \\
\hline SD & 420.1976 & 32.38902 & 132.673 & 86.17684 & 264.6514 & 549 & 437 & & 7.7605 \\
\hline \%RSD & 159.5312 & 181.2818 & 134.9217 & 131.329 & 101.886 & 101 & 543 & & .2281 \\
\hline \%Samples Exceed from EU-Limit & $43 \%(9)$ & $24 \%(5)$ & - & - & - & - & & - & \\
\hline \%Samples Exceed from U.S. Limit & $33 \%(7)$ & $9 \%(2)$ & - & $43 \%(9)$ & - & - & & - & \\
\hline \%Samples Exceed from Canadian Limit & $33 \%(7)$ & - & - & - & - & - & & - & \\
\hline \%Sample Exceed from BIS Limit & $33 \%(7)$ & $9 \%(2)$ & - & $43 \%(9)$ & - & - & & - & \\
\hline
\end{tabular}

\section{Figures}




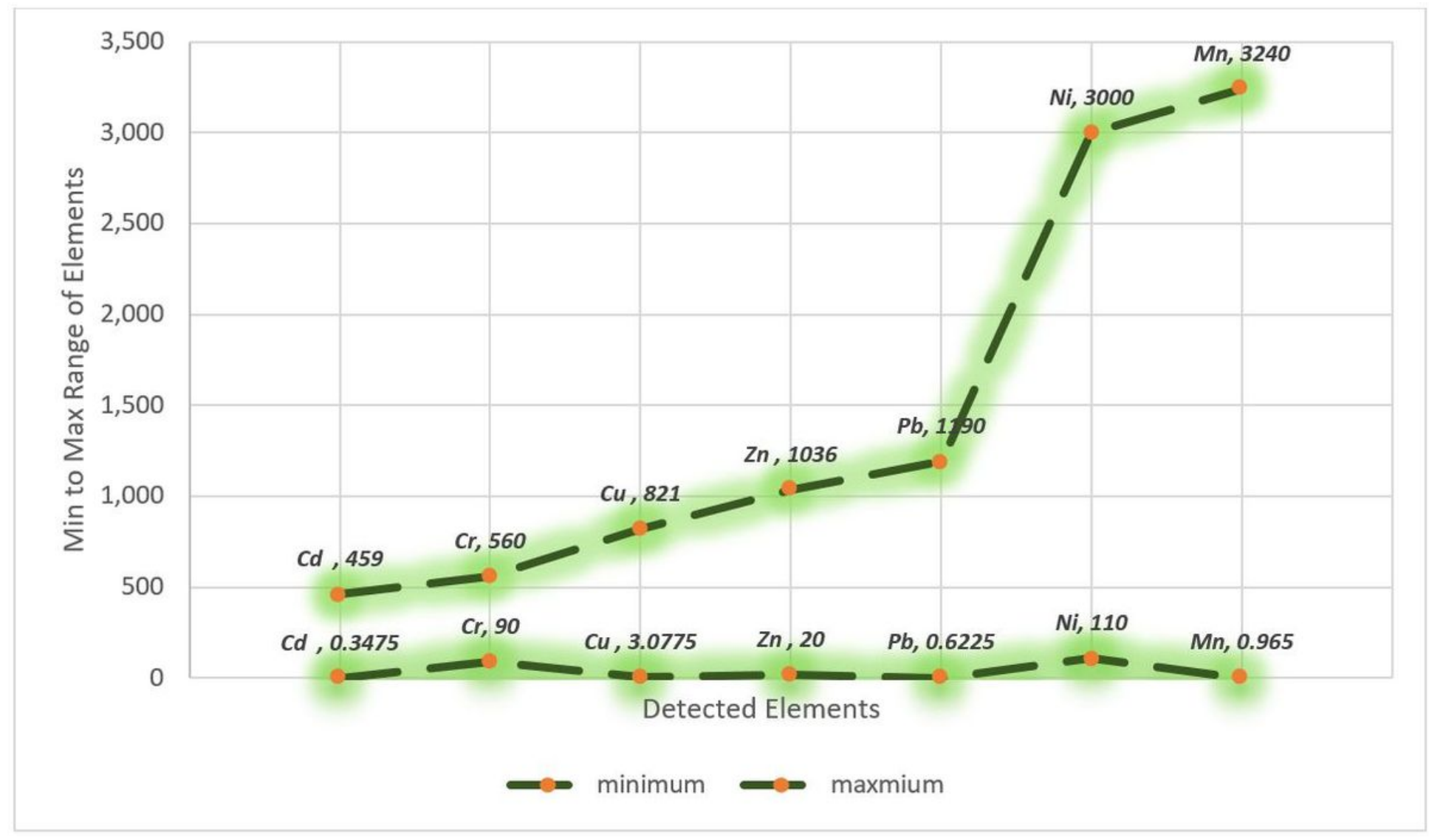

Figure 1

Minimum to maximium range of elements detected in toys samples.

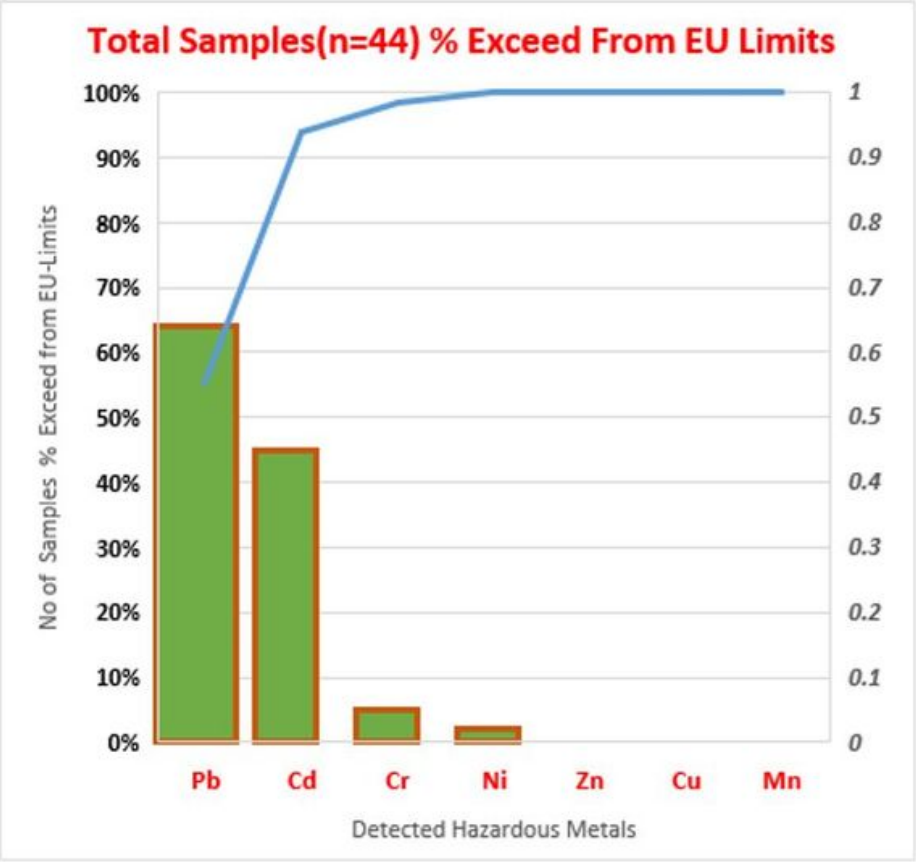

Figure 2a

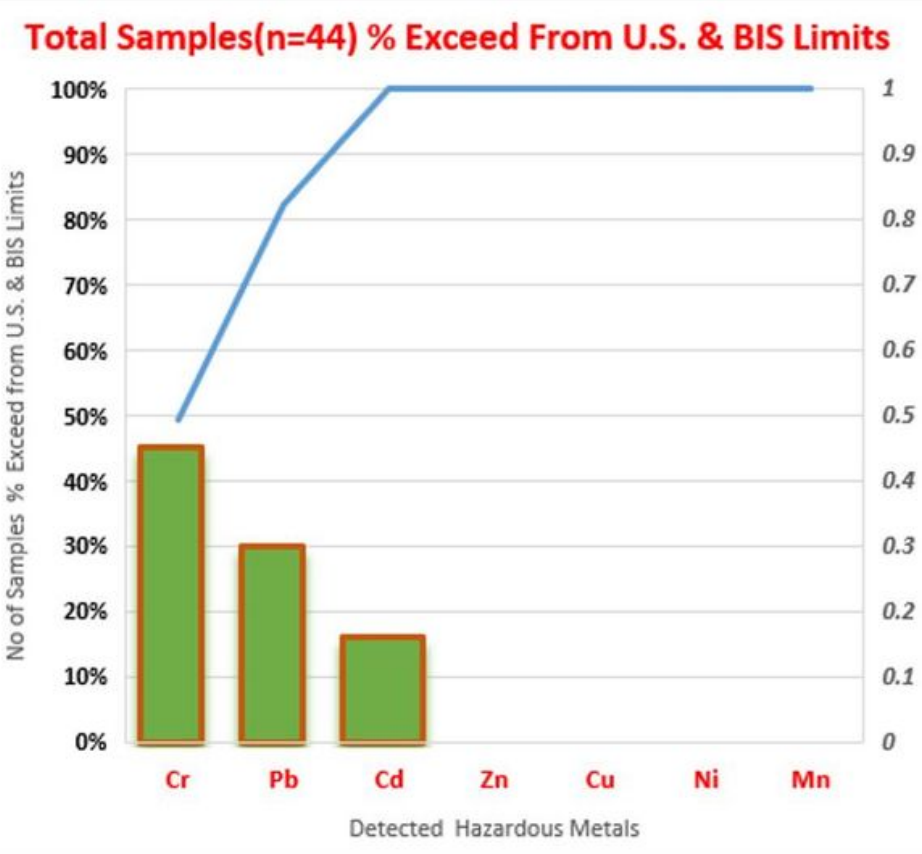

Figure 2b

\section{Figure 2}

Comparison of total metal concentrations of detected metals in low-priced children's toys $(n=44) 2 a)$ no of toys samples percentages exceed from EU regulation limits in total samples. $2 \mathrm{~b}$ ) no of samples percentages exceed from U.S. and BIS regulations limits in total samples. 


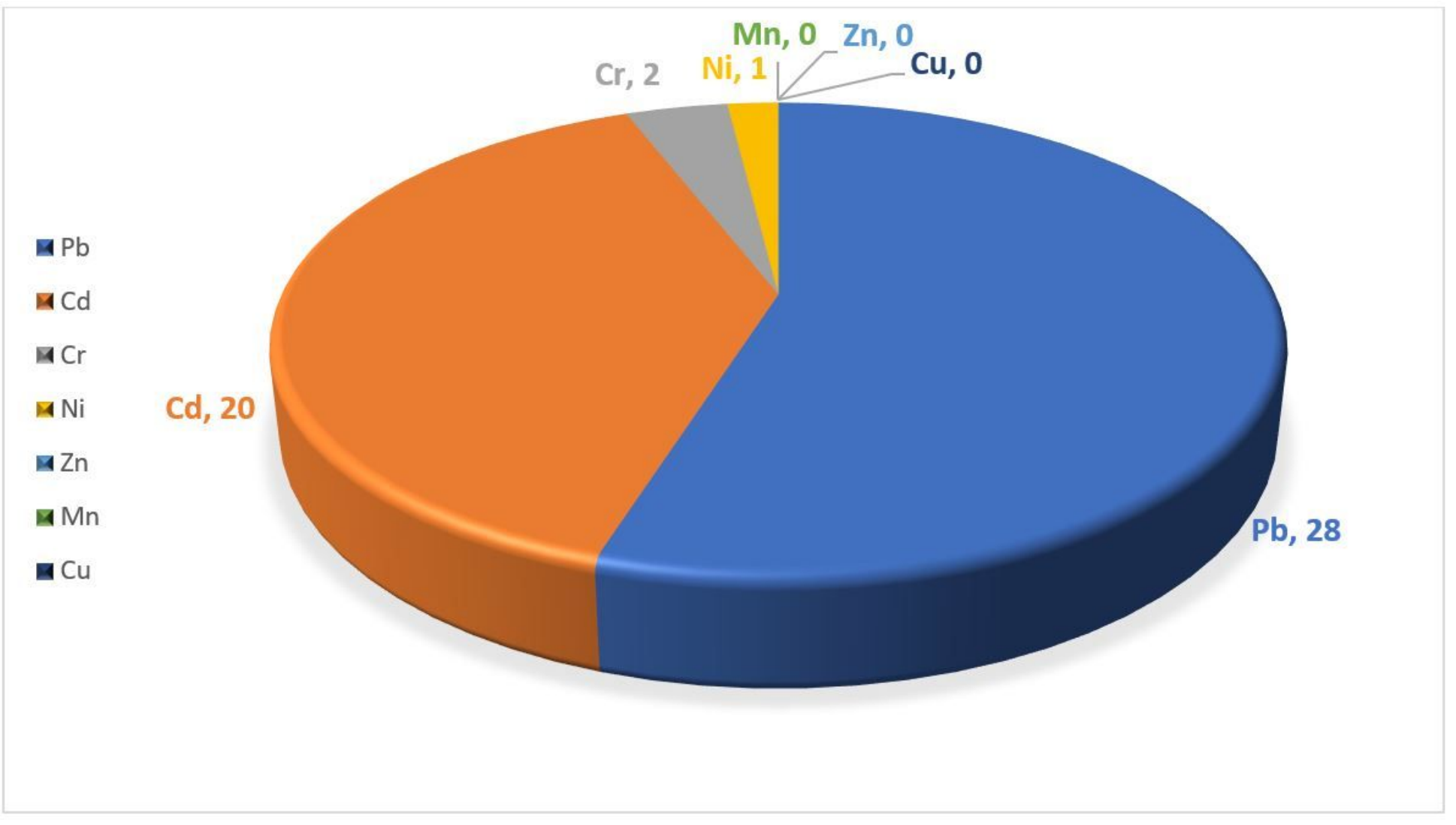

\section{Figure 3}

Representation of no of samples exceeds from toxic levels with respect to EU limits.

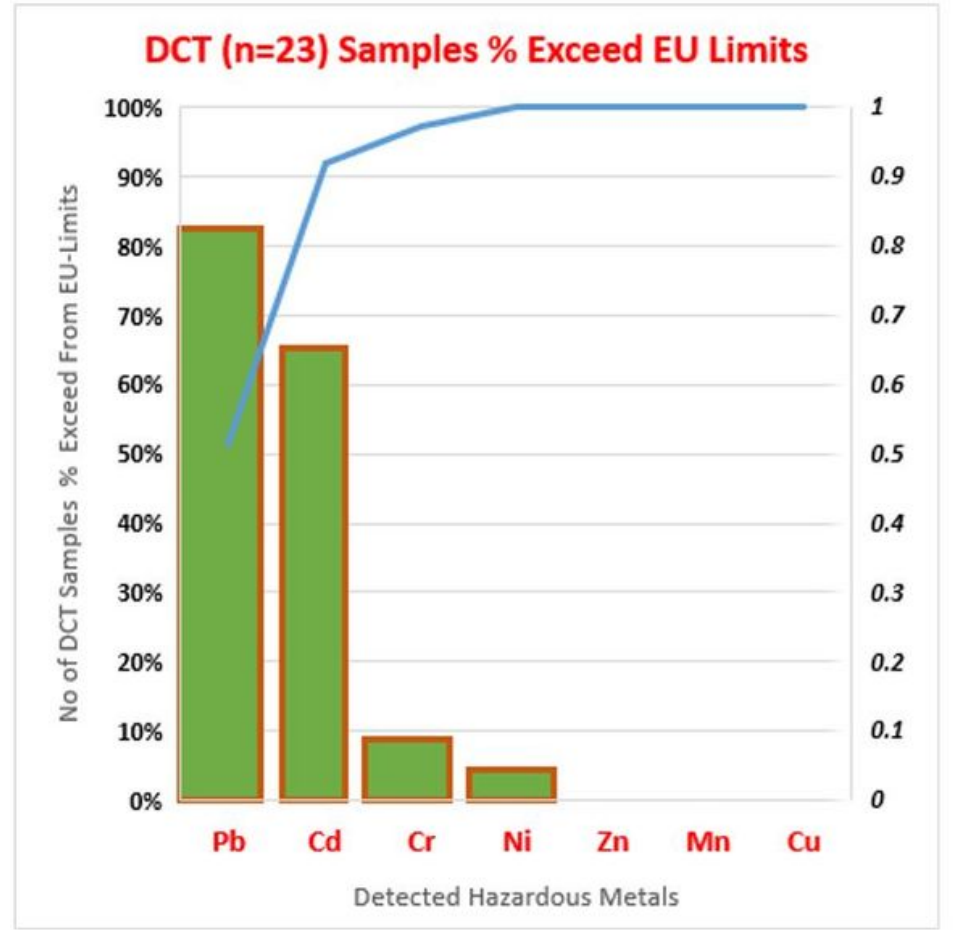

Figure 4a

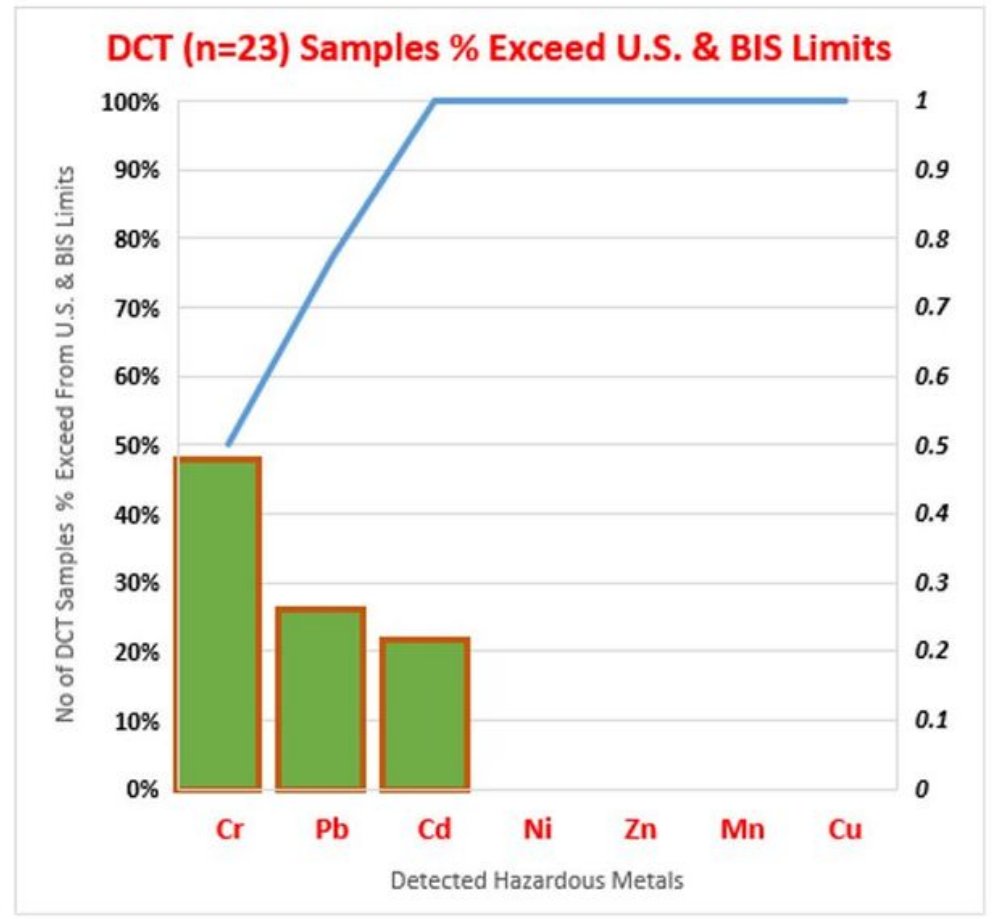

Figure 4b

\section{Figure 4}

Comparison of total metal concentrations of detected metals in low-priced children's toys $(n=44) 2 a)$ no of toys samples percentages exceed from EU regulation limits in total samples. 2 b) no of samples percentages exceed from U.S. and BIS regulations limits in total samples. 


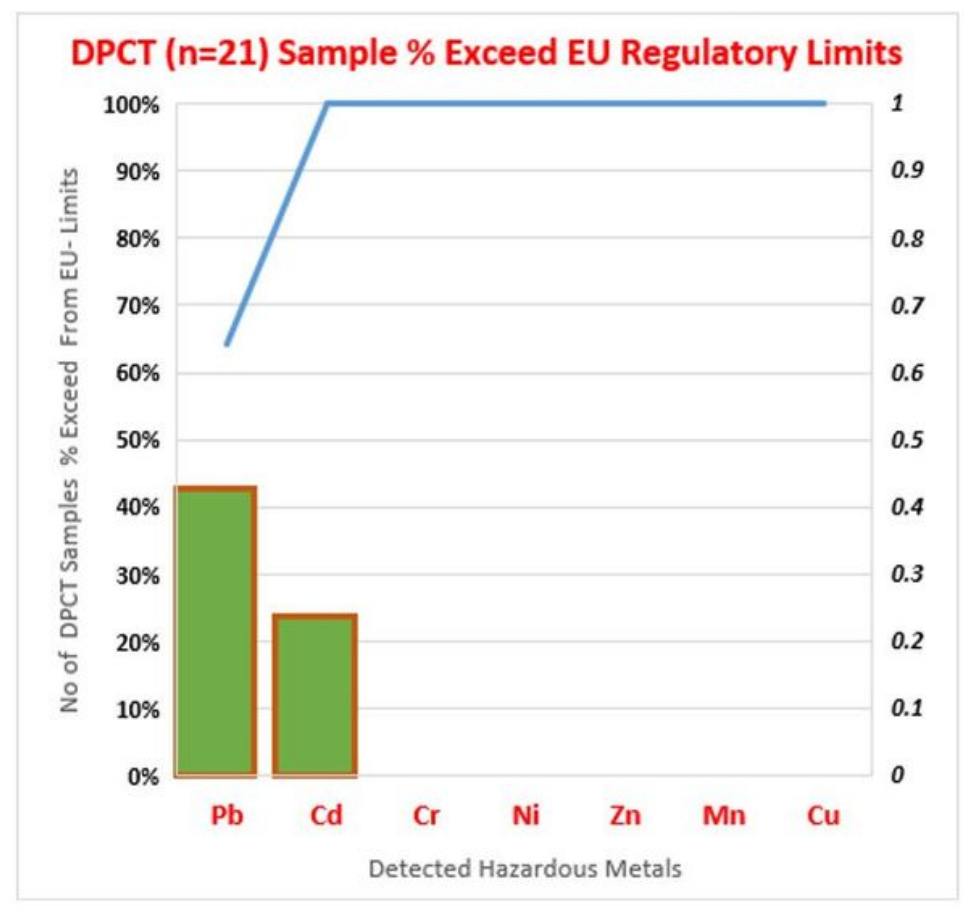

Figure 5a

\section{DPCT (n=21) Sample \% Exceed BIS, U.S., \& Canadian Regulatory Limits}

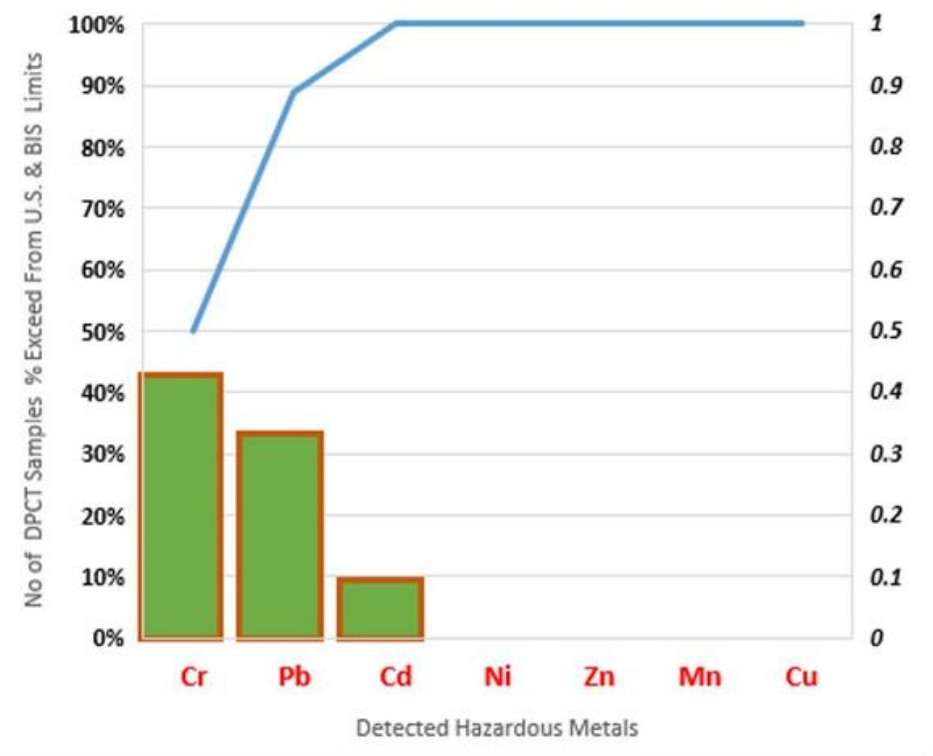

Figure 5b

\section{Figure 5}

Comparation of total metal concentrations of detected metals in low-priced children's plastics toys DPCT group ( $n=21$ ) $5 a$ ) no of toy samples percentages exceed from EU- Toy safety regulations limits in DPCT group. 5b) no of toy samples percentages exceed from U.S. and BIS toy safety regulations limits in DPCT group. 